\title{
BATASAN RUMAH SUSUN YANG DIJADIKAN AGUNAN PADA BANK
}

\author{
Rizal Bahrudin, J. Andy Hartanto \\ Universitas Narotama | Jl. Gayung Kebonsari Manunggal No 12, Surabaya \\ rizal.renvoi@gmail.com
}

Abstract: This article discusses existence and the authority of certificate executorial of guarantee right to ownership right of apartment as loan collateral in credit agreement in bank. The law of Apartment has become object of collateral which can be burdened with the law of Guarantee Right and can only be subject of ownership right on apartment because it is an independent property. The legal consideration of execution for guarantee right on apartment is stipulated in article 20 of the law, in which object of guarantee right is sold through public auction and certificate holder of guarantee right is entitled to take all or part of the revenue to pay debts with the right before other creditors. The article suggests that when applying the principle of prudence, banks would not be able to channel loan or credit without collateral. Ownership right on apartment may be used as object of credit collateral and bound with guarantee right.

Key words: Apartment, collateral, credit

Abstrak: Artikel ini membahas tentang eksistensi dan kekuatan eksekutorial sertifikat hak tanggungan terhadap hak milik atas satuan rumah susun sebagai jaminan hutang dalam perjanjian kredit di bank. Undang-Undang Rumah Susun telah menjadi objek agunan/jaminan yang dapat dibebani dengan oleh Undang-Undang Hak Tanggungan, dan hanya dapat dikenakan pada hak milik atas satuan rumah susun, karena merupakan kepemilikan seseorang yang merupakan bendabenda yang berdiri sendiri. Landasan hukum eksekusi hak tanggungan atas satuan rumah susun terdapat dalam Pasal 20 UUHT, di mana objek hak tanggungan dijual melalui pelelangan umum menurut cara yang ditentukan dalam peraturan perundang-undangan yang berlaku dan pemegang sertifikat hak tanggungan berhak mengambil seluruh atau sebagian dari hasilnya untuk pelunasan piutangnya, dengan hak yang mendahului dari pada kreditur yang lain. Hasil dari penulisan ini adalah dalam menjalankan prinsip kehati-hatian, bank tidak akan berani memberikan pinjaman atau kredit kepada masyarakat tanpa adanya

\footnotetext{
AL-DAULAH: JURNAL HUKUM DAN PERUNDANGAN ISLAM VOLUME 8, NOMOR 1, APRIL 2018 
jaminan. Hak milik atas satuan rumah susun dapat dijadikan objek jaminan kredit dan diikat dengan hak tanggungan.

Kata Kunci: Rumah susun, agunan, bank.

\section{Pendahuluan}

Kebutuhan atas tanah dewasa ini semakin meningkat sejalan dengan bertambahnya jumlah penduduk, jumlah badan usaha, dan meningkatnya kebutuhan lain yang berkaitan dengan tanah. Tanah tidak saja sebagai tempat bermukim, tempat untuk bertani, tetapi juga dapat dipakai sebagai jaminan untuk mendapatkan pinjaman di bank untuk keperluan jual beli dan sewa-menyewa. Banyak pihak yang tidak bertanggung jawab sengaja memanfaatkan celah dari meningkatnya harga jual tanah dengan ketersediaan tanah yang tidak sebanding, seperti dengan menjual tanah sengketa dengan harga yang cenderung lebih murah. Dari proses jual belinya, terlihat bahwa jual beli tanah tersebut sah secara hukum, namun ketika yang dijual ataupun yang dibeli adalah tanah sengketa, hal ini akan menimbulkan permasalahan hukum di kemudian hari. Hal tersebut sering kali terjadi karena minimnya pengetahuan masyarakat tentang hukum pertanahan.

Tujuan pembangunan nasional adalah untuk mewujudkan kesejahteraan lahir dan batin seluruh rakyat Indonesia secara adil dan merata, sebagai salah satu usaha untuk mengisi cita-cita perjuangan bangsa Indonesia bagi terwujudnya masyarakat adil dan makmur berdasarkan Pancasila dan Undang-Undang Dasar 1945. Salah satu unsur pokok kesejahteraan rakyat adalah terpenuhinya kebutuhan akan perumahan, yang merupakan kebutuhan dasar bagi setiap warga negara Indonesia dan keluarganya sesuai dengan harkat dan martabatnya sebagai manusia. Di samping itu, pembangunan perumahan merupakan salah satu unsur yang penting dalam strategi pengembangan wilayah, yang menyangkut aspek-aspek yang luas di bidang kependudukan, dan berkaitan erat dengan pembangunan ekonomi dan kehidupan sosial dalam rangka pemantapan ketahanan nasional. 
Guna mengatur penyelenggaraan rumah susun yang tertib dan berkepastian hukum, maka pemerintah membentuk peraturan perundang-undangan rumah susun. Pengaturan rumah susun untuk pertama kalinya diatur dalam Undang-Undang No. 16 Tahun 1985 tentang Rumah Susun, tetapi dalam perjalanannya undangundang tersebut tidak sesuai dengan perkembangan hukum, kebutuhan setiap orang dalam penghunian, kepemilikan, dan pemanfaatan rumah susun. Oleh karena itu kemudian diganti dengan Undang-Undang No. 21 tahun 2011 tentang Rumah Susun.

Seiring dengan perkembangan yang terjadi di masyarakat yaitu tuntutan pembangunan dan perkembangan hukum, kebutuhan setiap orang, terutama untuk memenuhi kebutuhan tempat tinggal yang terjangkau bagi masyarakat berpenghasilan rendah dan partisipasi masyarakat serta tanggung jawab dan kewajiban negara dalam penyelenggaraan rumah susun, maka Undang-undang Nomor 16 Tahun 1985 atau UURS yang pertama ini dipandang tidak memadai lagi dan perlu adanya penyempurnaan terhadapnya dan hal itu juga merupakan instruksi dari Pasal 46 Undang-undang Nomor 1 Tahun 2011 tentang Perumahan dan Kawasan Perumahan yang menetapkan bahwa ketentuan mengenai rumah susun diatur tersendiri dengan Undang-undang.

Sejalan dengan arah kebijaksanaan tersebut, maka di daerah perkotaan yang berpenduduk padat sedangkan tanah yang tersedia sangat terbatas, perlu dikembangkan pembangunan perumahan dan pemukiman dalam bentuk rumah susun yang lengkap, seimbang dan serasi dengan lingkungannya. Pengertian Rumah Susun adalah bangunan bertingkat yang distrukturkan secara fungsional dalam arah horizontal dan arah vertikal yang terbagi dalam satuan-satuan yang masing-masing jelas batas-batasnya, ukuran dan luasnya, dan dapat dimiliki dan dihuni secara terpisah ${ }^{1}$. Pasal 1 ayat (1) Undang-Undang Republik Indonesia Nomor 20

' Herman Hermit, Komentar Atas Undang-undang Rumah Susun, (Bandung: Mandar Maju, 2009), 5. 
Tahun 2011 menjelaskan Rumah susun adalah bangunan gedung bertingkat yang dibangun dalam suatu lingkungan yang terbagi dalam bagian-bagian yang distrukturkan secara fungsional, baik dalam arah horizontal maupun vertikal dan merupakan satuansatuan yang masing-masing dapat dimiliki dan digunakan secara terpisah, terutama untuk tempat hunian yang dilengkapi dengan bagian bersama, benda bersama dan tanah bersama.

Yang dapat memiliki satuan rumah susun adalah subjek hukum yang memenuhi syarat sebagai pemegang hak atas tanah karena pemilikan satuan rumah susun meliputi juga hak bersama atas tanah bersama. Subjek hukum di sini dapat perseorangan atau badan hukum, sebagaimana dinyatakan dalam Pasal 8 ayat (1) Undang-Undang No. 16 Tahun 1985². Kepemilikan satuan rumah susun atau bagian-bagian dari apartemen tersebut juga dilindungi oleh hukum, sehingga sesuai konsep hak milik, maka terhadap kepemilikan tersebut dapat dialihkan dan dibebankan dengan hak jaminan.

Strata title dapat diartikan juga hak atas lapisan, yang dikatakan hak atas lapisan adalah hak seseorang atau suatu pihak untuk dapat memiliki suatu ruangan bangunan yang berada diatas tanah atas bangunan orang lain. Hak milik atas satuan rumah susun (selanjutnya disebut HMSRS) merupakan lembaga hukum baru di negara Indonesia. Keberadaanya membawa konsekuensi terhadap peraturan-peraturan yang berkaitan dengan pemilikan bersama atas bangunan gedung bertingkat.

Hak milik atas satuan rumah susun yang bersifat hak perorangan (individu atau individu-individu secara bersama atau badan hukum tertentu) mengikuti persyaratan subyek, yakni subyek hukum yang diperbolehkan untuk memiliki. Apabila perseorangan memenuhi syarat sebagai subyek hukum hak atas tanah, baik hak milik, hak guna bangunan, hak pakai sebagaimana

2 Adrian Sutedi, Hukum Rumah Susun \& Apartemen, (Bandung: Sinar Grafika, 20 I 2), 2 I I . 
diatur dalam hukum agraria, maka perseorangan dimaksud memenuhi syarat kepemilikan hak atas rumah susun.

J. Andy Hartanto menyatakan peralihan atau pemindahan hak adalah suatu perbuatan hukum yang bertujuan untuk memindahkan hak dari suatu pihak ke pihak lain. Pengalihan hak atas tanah dan/ atau bangunan adalah: Penjualan, tukar menukar, perjanjian pemindahan hak, pelepasan hak, penyerahan hak, lelang, hibah, atau cara lain yang disepakati dengan pihak lain selain pemerintah guna pelaksanaan pembangunan termasuk pembangunan untuk kepentingan umum yang tidak memerlukan persyaratan khusus. ${ }^{3}$ Ada 2 (dua) cara dalam mendapatkan ataupun memperoleh hak milik, yakni:

1. Dengan pengalihan, yang meliputi beralih dan dialihkan dalam hal ini berarti ada pihak yang kehilangan yaitu pemilik semula dan pihak lain yang mendapatkan suatu hak milik.

2. Terjadinya hak milik sesuai dengan Undang-Undang Pokok Agraria Nomor 5 Tahun 1960 pada pasal 22.

Dalam jurnal ini dibahas mengenai rumah susun yang dijadikan agunan pada bank dan kekuatan eksekutorial sertifikat hak tanggungan terhadap hak milik atas satuan rumah susun sebagai jaminan pada hank, serta syarat-syarat sahnya satuan rumah susun sebagai jaminan kredit.

\section{Ruang Lingkup Rumah Susun dan Satuan Rumah Susun}

Pemerintah melakukan berbagai upaya memenuhi kebutuhan masyarakat akan perumahan, terutama di daerah-daerah yang berpenduduk padat dan tersedianya tanah sangat terbatas, yaitu dengan melaksanakan pembangunan perumahan menggunakan sistem rumah susun sebagai salah satu alternatif pemecahan masalah kebutuhan perumahan dan permukiman untuk memperkecil penggunaan tanah, membuat ruang terbuka dalam perkotaan dan mengurangi daerah kumuh.

${ }^{3}$ J.Andy Hartanto dan Eman Ramelan, Problematika Hukum Hak Milik atas Satuan Rumah Susun, (Yogyakarta: Laksbang Grafika, 20।3), 86. 
Pengaturan mengenai UURS yang pertama ini mulai berlaku pada tanggal 31 Desember 1985, yang memantapkan mengenai tata aturan hukum terhadap hal-hal yang berkaitan dengan rumah susun yang didukung oleh Peraturan Pemerintah Nomor 4 Tahun 1988, yang kemudian disebut dengan PP Nomor 4 Tahun 1988 tentang Rumah Susun.7 Sehingga UURS yang pertama ini dikatakan sebagai peletak dasar hukum bagi semua jenis dan berbagai macam model bangungan gedung bertingkat tinggi dengan fungsi sebagai hunian.

Sebagai tindakan untuk memenuhi tuntutan dan instruksi di atas, kemudian diterbitkan Undang-undang Nomor 20 Tahun 2011 tentang rumah susun yang ditetapkan pada 10 Nopember 2011, yang selanjutnya akan disebut sebagai UURS yang baru sebagai penyempurnaan produk hukum untuk mengatur tentang pengaturan penyelenggaraan rumah susun secara menyeluruh.

Menteri Negara Agraria atau Kepala Badan Pertanahan Nasional menyatakan bahwa istilah rumah susun merupakan terjemahan dari kata-kata condominium, flat atau apartement yang digunakan berdasarkan sistem hukum tiap negara masing-masing, misalnya di Amerika yang menggunakan istilah condominium, di Inggris yang menggunakan istilah joint property, sedangkan di Singapura dan Australia menggunakan istilah strata title. ${ }^{4}$

Hak milik satuan rumah susun memiliki konsep dasar bahwa benda atau bangunan dapat dimiliki oleh seseorang, dua orang, atau bahkan lebih yang mana hal tersebut dikenal dengan istilah pemilikan bersama. Bentuk pemilikan bersama ini terbagi atas dua yaitu pemilikan bersama yang terikat dan pemilikan bersama yang

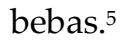

${ }^{4}$ Oloan Sitorus dan Balans Sebayang, Kondominium dan Permasalahannya, (Yogyakarta: Mitra Kebijakan Tanah Indonesia, 1998), 8.

${ }^{5}$ Adrian Sutedi, Hukum Rumah Susun dan Apartemen, (Jakarta: Sinar Grafika, 20 I0), 198. 


\section{Pemberian Hak Tanggungan atas Hak Milik Satuan Rumah Susun}

Pasal 1 Ayat (1) UUHT disebutkan bahwa: "Hak tanggungan adalah hak jaminan yang dibebankan pada hak atas tanah sebagaimana dimaksud dalam Undang-undang Nomor 5 Tahun 1960 tentang Peraturan Dasar Pokok-Pokok Agraria, berikut atau tidak berikut benda-benda lain yang merupakan satu kesatuan dengan tanah itu, untuk pelunasan utang tertentu, yang memberikan kedudukan yang diutamakan kepada kreditur tertentu terhadap kreditur-kreditur lain."

Menurut Salim, hukum jaminan adalah keseluruhan kaidahkaidah hukum yang mengatur hubungan hukum antara pemberi dan penerima jaminan dalam kaitannya dengan pembebanan jaminan untuk mendapatkan fasilitas kredit. ${ }^{6}$

Unsur-unsur yang tercantum dalam definisi Salim adalah:

1) Adanya kaidah hukum

Kaidah hukum dalam bidang jaminan, dapat dibedakan menjadi 2 macam, yaitu kaidah hukum jaminan tertulis dan kaidah hukum jaminan tidak tertulis. Kaidah hukum jaminan tertulis adalah kaidah-kaidah hukum yang terdapat dalam peraturan perundang-undangan, trakat dan yurisprudensi. Sedangkan kaidah hukum jaminan tidak tertulis adalah kaidahkaidah hukum jaminan yang tumbuh, hidup dan berkembang dalam masyarakat. Hal ini terlihat pada gadai tanah dalam masyarakat yang dilakukan secara lisan.

2) Adanya pemberi dan penerima jaminan

Pemberi jaminan adalah orang-orang atau badan hukum yang menyerahkan barang jaminan kepada penerima jaminan. Yang bertindak sebagai pemberi jaminan ini adalah orang atau badan hukum yang membutuhkan fasilitas kredit. Orang ini lazimnya disebut debitur. Penerima jaminan adalah orang atau badan hukum penerima barang jaminan dan pemberi jaminan.

\footnotetext{
${ }^{6}$ Salim, Perkembangan Hukum Jaminan di Indonesia, (Depok: Raja Grafindo Persada, 20 I6), 6.
} 
Yang bertindak sebagai penerima jaminan ini adalah orang atau badan hukum. Badan hukum adalah lembaga yang memberikan fasilitas kredit, dapat berupa lembaga perbankan dan atau lembaga keuangan non bank.

3) Adanya jaminan

Pada dasarnya, jaminan yang diserahkan kepada kreditur adalah jaminan materiil dan imateriil. Jaminan materiil merupakan jaminan yang berupa hak-hak kebendaan, seperti jaminan atas benda bergerak dan benda tidak bergerak. Jaminan imateriil merupakan jaminan non kebendaan.

4) Adanya fasilitas kredit

Pembebanan jaminan yang dilakukan oleh pemberi jaminan bertujuan untuk mendapatkan fasilitas kredit dari bank atau lembaga keuangan non bank lainnya. Pemberian kredit merupakan pemberian uang berdasarkan kepercayaan, dalam arti bank atau lembaga keuangan non bank percaya bahwa debitur sanggup untuk mengembalikan pokok pinjaman dan bunganya. Begitu juga debitur percaya bahwa bank atau lembaga keuangan non bank dapat memberikan kredit kepadanya.

Yang termasuk dalam jaminan bergerak meliputi: gadai dan fidusia. Sedangkan jaminan benda tidak bergerak meliputi hak tanggungan, fidusia, khususnya rumah susun, hipotik kapal laut dan pesawat udara.

Pemberian hak tanggungan pada hak milik satuan rumah susun terdiri dari beberapa tahap tertentu yang mana tahap-tahap tersebut adalah merupakan bagian dari proses yuridis dan administrati.

a) Perjanjian kredit

Perjanjian kredit tersebut merupakan suatu perjanjian pokok (basic agreement, principal agreement), yang berfungsi sebagai dokumen pertama atau sebagai dokumen awal untuk membuktikan ada terjadinya perjanjian utang. Berdasarkan Pasal 10 ayat (1) UUHT yang berbunyi: 
"Pemberian hak tanggungan didahului dengan janji untuk memberikan hak tanggungan sebagai jaminan pelunasan utang tertentu, yang dituangkan di dalam dan merupakan bagian tak terpisahkan dari perjanjian utang-piutang yang bersangkutan atau perjanjian lainnya yang menimbulkan utang tersebut."

Perjanjian hak tanggungan bersifat accessoir dengan perjanjian pokok. Suatu hak tanggungan tidak dapat berdiri sendiri, tetapi merupakan ikutan dari perjanjian pokok.

b) Pembuatan Akta Pemberian Hak Tanggungan

Pemberian hak tanggungan didukung dengan pembuatan Akta Pemberian Hak Tanggungan atau disingkat dengan istilah APHT yang dibuat oleh Pejabat Pembuat Akta Tanah (PPAT) dan akta ini berfungsi sebagai bukti tentang pemberian hak tanggungan yang berkedudukan sebagai dokumen perjanjian kedua, melengkapi dokumen perjanjian utang (perjanjian pokok) ${ }^{7}$.

Adapun dalam pembuatan suatu APHT oleh seorang PPAT menurut Pasal 11 UUHT, wajib mencantumkan nama dan identitas pemegang dan pemberi HT, domisili dari pihak-pihak tersebut, penunjukan secara jelas tentang utang yang dijaminkan, nilai tanggungan, dan uraian mengenai objek hak tanggungan yaitu dalam hal ini satuan rumah susun yang akan dijadikan jaminan utang.

c) Peraturan Kepala Badan Pertanahan Republik Indonesia Nomor 8 Tahun 2012

Peraturan Kepala Badan Pertanahan Nasional Republik Indonesia Nomor 8 Tahun 2012 yang selanjutnya disebut dengan Perkaban Nomor 8 Tahun 2012 ini, maka PPAT untuk seterusnya harus membuat dan menyusun akta tersebut secara pribadi karena tidak dibenarkan lagi mempergunakan blanko.

Hal tersebut sesuai dengan isi Perkaban Nomor 8 Tahun 2012 pada bagian menimbang huruf a yaitu:

7 M. Yahya Harahap, Ruang Lingkup Permasalahan Eksekusi Bidang Perdata, (Jakarta: Sinar Grafika, 2009), 190. 


\begin{abstract}
“Bahwa untuk meningkatkan pelayanan pertanahan, terhitung mulai tahun 2013 penyiapan dan pembuatan blanko Akta Pejabat Pembuat Akta Tanah dilakukan oleh masing-masing Pejabat Pembuat Akta Tanah, Pejabat Pembuat Akta Tanah pengganti, Pejabat Pembuat Akta Tanah sementara atau Pejabat Pembuat Akta Tanah Khusus."
\end{abstract}

Pendaftaran hak tanggungan merupakan syarat imperatif yaitu suatu syarat yang diharuskan. Setelah penandatanganan akta, seorang PPAT sebagai pembuat APHT berdasarkan Pasal 13 ayat (2) UUHT, berkewajiban mengirimkan APHT dan warkat lain yaitu meliputi surat-surat bukti yang berkaitan dengan objek hak tanggungan dan identitas para pihak, serta sertifikat hak atas tanah yang diperlukan kepada kantor pertanahan selambat-lambatnya 7 (tujuh) hari kerja dari tanggal penandatanganan APHT.

Fungsi dari adanya sertifikat hak tanggungan ini adalah sebagai bukti atas hak tanggungan dan sebagaimana tercantum dalam Pasal 14 ayat (3) yang menyatakan bahwa setifikat ini adalah sebagai landasan kekuatan eksekutorial yang mana kekuatannya sama dengan putusan pengadilan yang telah berkekuatan hukum tetap.

Adapun tindakan yang dilakukan selanjutnya oleh kantor pertanahan adalah mengembalikan sertifikat tanah yang berisi catatan pemberian hak tanggungan tersebut kepada pemegang hak tanah dan sekaligus memberikan sertifikat hak tanggungan kepada pihak kreditur.

\title{
Hubungan antara Hak Milik Satuan Rumah Susun sebagai Objek Hak Tanggungan terhadap Hak atas Tanah di mana Bangunan Rumah Susun tersebut Berdiri
}

Perbuatan hukum yang berkaitan dengan satuan rumah susun selalu dihubungkan dengan tanah, di mana bangunan rumah susun itu berdiri atau dibangun. Sebagai akibat dari rumah susun tidak terlepas dari tanah, maka titik tolak pengaturannya berdasarkan Hukum Tanah Nasional dan hal ini merupakan konsekuensi logis 
adanya unifikasi Hukum Tanah sejak tanggal 24 September 1960, di mana semua ketentuan Buku II KUHPerdata sepanjang mengatur bumi, air dan kekayaan alam yang terkandung didalamnya dinyatakan tidak berlaku lagi kecuali mengenai hipotik. ${ }^{8}$

Hubungan hak milik satuan rumah susun dengan tanahnya merupakan hukum perdata, artinya kewenangan pemegang hak milik tersebut untuk berbuat sesuatu atas tanahnya sebatas hak yang diberikan oleh negara yang memiliki kewenangan publik, sebagaimana diatur dalam peraturan perundang-undangan yang berlaku, maka dari itu, orang atau badan hukum sebagai pemegang hak milik tidak boleh melakukan hal-hal di luar haknya.

Sehubungan hal tersebut dengan lingkup hukum perdata, yang mana tentang kewenangan berbuat sesuatu atas tanah, maka pemegang hak dapat melakukan perbuatan hukum atas tanah tersebut. Hal ini juga terjadi pada pemegang hak milik satuan rumah susun, yang mana hak milik tersebut memberikan kewenangan kepada mereka agar dapat melakukan berbagai tindakan hukum seperti jual beli, hibah atau yang lebih khusus dibahas disini yaitu untuk dijadikan jaminan utang.

Dalam praktik perbankan, jaminan ini diartikan secara luas meliputi agunan dan penanggungan, baik bersifat perorangan maupun jaminan perusahaan. Jaminan secara sempit hanya agunan saja, yang meliputi benda bergerak dan tidak bergerak, sedangkan agunan pokok adalah barang, proyek, atau hak tagih yang dibiayai dengan fasilitas pembiayaan, dan agunan tambahan merupakan barang-barang lain yang tidak dibiayai dengan fasilitas pembiayaan. ${ }^{9}$ Dengan pemaknaan demikian pula, dapat dipahami bahwa agunan (jaminan kredit) ini merupakan jenis perjanjian accesoir yang mengikuti perjanjian pokok, di mana hal ini merupakan bagian dari realisasi prinsip kredit melalui collateral, serta berimplikasi pada status krediturnya sebagai kreditur sparatis yakni kreditur pemegang jaminan kebendaan.

${ }^{8}$ Adrian Sutedi, Hukum Rumah Susun dan Apartemen, 196.

9 Wangsawidjaja Z., Pembiayaan Bank Syariah, (Jakarta: Gramedia Pustaka Utama, 201 2), 288. 
Pengaturan jaminan yang termuat dalam Kitab UndangUndang Hukum Perdata Buku II tentang Benda dan Buku III tentang Perikatan. Jaminan umum yang bersumber dari undangundang10, yaitu Kitab Undang-Undang Hukum Perdata (KUH Perdata) yang kaidahnya berbunyi: Segala kebendaan si berutang, baik yang bergerak maupun yang tidak bergerak, baik yang sudah ada maupun yang baru akan ada di kemudian hari, menjadi tanggungan untuk segala perikatan-perikatan perseorangan (Pasal 1131), dalam ketentuan Pasal 1132 ditentukan bahwa kebendaan tersebut menjadi jaminan bersama-sama bagi semua orang yang mengutang padanya; pendapatan penjualan benda-benda itu dibagi-bagi menurut keseimbangan, yaitu menurut besar kecilnya piutang masing-masing, kecuali apabila di antara para berpiutang itu ada alasan-alasan yang sah untuk didahulukan. Dan Jaminan khusus berdasarkan perjanjian, yaitu hipotik, gadai, fiducia dan penanggungan atau jaminan pribadi.

Istilah jaminan merupakan terjemahan dari bahasa Belanda, yaitu zekerheid atau cautie. Zekerheid atau cautie mencakup secara umum cara-cara kreditur menjamin dipenuhinya tagihannya, di samping pertanggungan jawab umum debitur terhadap barangbarangnya. ${ }^{11}$ Pasal 47 ayat (5) UU Rumah Susun menyatakan, "SHM sarusun dapat dijadikan jaminan utang dengan dibebani hak tanggungan sesuai dengan ketentuan peraturan perundangan-undangan" Berdasarkan ketentuan tersebut, maka HMSRS dapat dijadikan sebagai jaminan kredit dengan dibebani hak tanggungan. Ketentuan ini sejalan dengan UUHT, sebagai implementasi dan Pasal 51 UUPA. Pasal 27 UUHT menyebutkan bahwa "Ketentuan UUHT ini berlaku terhadap pembebanan hak jaminan atas rumah susun dan HMSRS". Sehingga dapat dijadikannya rumah susun/HMSRS sebagai jaminan kredit diatur secara limitative dalam UUHT.

\footnotetext{
10 Sri Soedewi Masjchoen Sofwan, Hukum Jaminan di Indonesia, Pokok-pokok Hukum Jaminan dan Jaminan Perorangan, (Yogyakarta: BPHN dan Liberty, 1980), 43-46.

I Salim, Perkembangan Hukum Jaminan di Indonesia, (Jakarta: Rajawali Pers, 2008), 21.
} 
Hak tanggungan adalah hak jaminan yang dibebankan pada Hak atas tanah, sebagaimana dimaksud dalam Undang-Undang Nomor 5 Tahun 1960 tentang Dasar Pokok-Pokok Agraria, hak tanggungan merupakan salah satu lembaga hak jaminan kebendaan, yang lahir dari perjanjian, yaitu perjanjian kredit yang merupakan suatu perjanjian yang lazim dilakukan dalam bidang hukum perbankan. Di dalam perjanjian kredit ada dua pihak yang terlibat yaitu bank selaku kreditor dan nasabah selaku debitor. Dalam perjanjian kredit biasanya disertakan pula adanya jaminan kebendaan untuk menjamin pelunasan utang debitor. Jaminan kebendaan tersebut harus dibuatkan dalam suatu perjanjian jaminan yang memiliki hak kebendaan dan bersifat accesoir (tambahan). Salah satu jaminan dengan hak kebendaan adalah hak tanggungan.

Berdasarkan ketentuan Pasal 27 UUHT, maka dapat difahami bahwa setelah berlakunya UUHT, rumah susun tidak lagi dimungkinkan dijamin dengan hipotik dan fidusia, karena yang menjadi objek jaminan dengan hipotik dan fidusia di dalam UURS telah menjadi objek jaminan yang dalam dibebani dengan HT oleh UUHT.

Salah satu jenis jaminan yang berkembang saat ini yaitu rumah susun. Sebagai pemegang hak milik rumah susun, pemilik rumah susun dapat mengajukan kredit dengan menjadikan sertifikat hak milik atas satuan rumah susun yang dimilikinya sebagai jaminan dalam bank. Jaminan tersebut dibebani dengan hak tanggungan bahwa dalam hal ini yang menjadi objek jaminan kredit dan diikat dengan hak tanggungan adalah bukan tanahnya tetapi hak milik atas satuan rumah susunnya beserta bagian bersama, benda bersama sebesar bagian pemilik hak milik atas satuan rumah susun.

Pada setiap bagian satuan rumah susun adalah bersifat terbagibagi dan merupakan milik masing-masing dari para pemegang hak yang berbeda-beda di setiap satuannya. Terhadap bagian tersebut, pemegang hak milik atas satuan tersebut, secara pribadi dapat membebankan satuan rumah susunnya dengan tanpa mengganggu 
kepentingan dari pemilik satuan rumah susun yang ada di sekitarnya kepada kreditur untuk dapat dibebankan hak tanggungan. Kewenangan yang dimiliki pemegang hak milik satuan rumah susun tersebut terhadap satuan rumah susun miliknya adalah diperbolehkan, karena sejalan dengan isi Pasal 27 UUHT yang menyatakan bahwa: "Ketentuan undang-undang ini berlaku juga terhadap pembebanan hak jaminan atas rumah susun dan hak milik atas satuan rumah susun", maka selanjutnya dimungkinkan suatu satuan rumah susun dapat dijadikan salah satu objek hak tanggungan.

Pengaturan tentang objek hak tanggungan yang diatur dalam Undang-Undang Hak Tanggungan diatur dalam Pasal 4 sampai dengan Pasal 7. Pasal 4 Undang-Undang Hak Tanggungan menyebutkan:

1) Hak atas tanah yang dapat dibebani hak tanggungan adalah
a. Hak milik
b. Hak guna usaha
c. Hak guna bangunan

2) Selain hak-hak atas tanah sebagaimana dimaksud dalam ayat (1), hak pakai atas tanah negara yang menurut ketentuan yang wajib didaftar dan menurut sifatnya dapat dipindahtangankan dapat juga dibebani hak tanggungan;

3) Pembebanan hak tanggungan pada hak pakai atas hak milik akan diatur lebih lanjut dengan peraturan pemerintah.

4) Hak tanggungan dapat juga dibebankan pada hak atas tanah berikut agunan, tanaman, dan hasil karya yang telah ada atau akan ada yang merupakan suatu kesatuan dengan tanah tersebut, dan merupakan milik pemegang hak atas tanah yang pembebanannya dengan tegas dinyatakan di dalam Akta Pemberian Hak Tanggungan yang bersangkutan.

5) Apabila bangunan, tanaman, dan hasil karya sebagaimana dimaksud dalam ayat (4) tidak dimiliki oleh pemegang hak atas tanah, pembebanan hak tanggungan atas benda-benda tersebut hanya dapat dilakukan dengan penandatanganan serta pada 
Akta Pemberian Hak Tanggungan yang bersangkutan oleh pemiliknya atau yang diberi kuasa untuk itu olehnya dengan akta otentik.

Hak atas tanah dalam rumah susun tidak dapat dibebakan dengan hak tanggungan, karena itu adalah tanah bersama yang merupakan milik kolektif. Dia dimungkinkan untuk dijaminkan dengan hak tanggungan hanya oleh developer pada saat membangun rumah susun tersebut, tapi kalau sudah berdiri rumah susunnya tidak mungkin lagi dapat dibebani dengan hak tanggungan, yang mungkin hanyalah hak milik atas satuan rumah susun karena itulah yang merupakan kepemilikan seseorang yang merupakan benda-benda yang berdiri di atas tanah bersama.

Pembebanan HMSRS sebagai jaminan kredit didasarkan karena adanya perjanjian kredit, di mana perjanjian jaminan yang merupakan perikatan antara kreditor dengan debitor atau pihak ketiga yang isinya menjamin pelunasan utang yang timbul dari pemberian kredit. Perjanjian jaminan kredit merupakan perjanjian yang bersifat accessoir, yaitu senantiasa merupakan perjanjian yang dikaitkan dengan perjanjian pokok.

Pada dasarnya, yang dijadikan objek adalah hak milik atas satuan rumah susunnya bukan tanahnya, namun hak milik atas satuan rumah susunnya. Tidak semua satuan rumah susun bisa dijadikan sebagai jaminan kredit, yang bisa dijadikan jaminan kredit hanyalah rumah susun yang dibangun di atas tanah HGB, atau hak pakai di atas tanah negara. Sedangkan untuk rumah susun yang dibangun diatas tanah HGB atau hak pakai atas tanah hak pengelolaan dapat dibebani setelah mendapat persetujuan dari pemegang hak pengelolaan tanpa dipungut biaya. ${ }^{12}$

Syarat-syarat sahnya satuan rumah susun sebagai jaminan utang juga tercantum pada Pasal 47 ayat (5) UURS, yang menyebutkan bahwa "Sertifikat Hak Milik sarusun dapat dijadikan jaminan utang dengan dibebani sesuai dengan ketentuan peraturan

12 Taufik Lan Tanamu, "Kedudukan Hak Milik atas Satuan Rumah Susun sebagai Jaminan Kredit Perbankan", Lex Privatum Universitas Samratulangi, Vol. III No. 2 (April-Juni 20 I5). 
perundang-undangan". Syarat-syarat yang harus dimiliki satuan rumah susun agar dapat dijadikan sebagai jaminan utang berdasarkan Pasal 13 UURS adalah yang dapat dijadikan jaminan hutang dengan hipotik atau disebut juga sekarang dengan hak tanggungan. Oleh karena itu yang sudah dijelaskan sebelumnya tentang satuan rumah susun yang dijadikan obyek jaminan bukan tanahnya melainkan hak milik atas satuan rumah susunnya.

Satuan rumah susun yang dapat dijadikan jaminan utang tersebut memiliki syarat-syarat tertentu, yaitu:

a) Berdasarkan Pasal 13 UURS yang pertama, satuan rumah susun dapat dijadikan jaminan hutang dengan hipotik atau sekarang disebut dengan hak tanggungan, jika tanahnya berupa tanah hak milik maupun hak guna bangunan dan juga dapat dijadikan jaminan hutang dengan fidusia apabila tanahnya merupakan tanah hak pakai atas tanah negara.

b) Berdasarkan Pasal 14 UURS yang pertama, terhadap pemberian jaminan tersebut wajib didaftarkan pada kantor pertanahan setempat untuk dicatatkan pada buku tanah dan sertifikat tersebut dan kemudian diterbitkan sertifikat hak tanggungannya.

c) Satuan rumah susun memiliki karakteristik yang sama dengan hak atas tanah yang dapat dijadikan objek hak tanggungan, karena meskipun merupakan satu bagian dengan keseluruhan bangunan rumah susun, akan tetapi terhadap satuannya masing-masing para penghuninya memegang hak milik yang dapat dijadikan jaminan utang.

Dalam proses pemberian hak milik satuan rumah susun, pada tahap awalnya dilakukan suatu pengikatan perjanjian kredit atau perjanjian utang, di mana disepakati janji debitur untuk memberikan sebagai jaminan pelunasan utang. Tahap selanjutnya adalah pembuatan akta atau disingkat APHT yang dibuat oleh (PPAT) dan akta ini berfungsi sebagai bukti tentang pemberian yang sesuai dengan peraturan perundang-undangan yang berlaku, kemudian pendaftaran pemberian hak tanggungan, merupakan 
syarat imperatif yaitu suatu syarat yang diharuskan. Hal tersebut yang menyebabkan tersebut wajib didaftarkan pada kantor pertanahan karena merupakan sebagai asas publisitas serta sebagai syarat mutlak untuk lahirnya dan mengikatnya terhadap pihak ketiga.

\section{Kekuatan Eksekusi untuk Rumah Susun}

Berdasarkan Pasal 20 UUHT terdapat kemungkinan yang dapat dilakukan kreditur terhadap objek hak tanggungan, apabila seorang debitur cidera janji yaitu melaksanakan parate executie, yang mana merupakan suatu pelaksanaan eksekusi tanpa melalui bantuan pengadilan, yang mana apabila debitur cidera janji, maka kreditur berhak untuk menjual objek hak tanggungan atas kekuasaan sendiri melalui pelelangan umum menurut tata cara yang ditentukan dalam peraturan perundang-undangan untuk pelunasan piutangnya dari hasil penjualan tersebut ${ }^{13}$

Landasan hukum atas eksekusi sertipikat hak tanggungan atas satuan rumah susun terdapat dalam Pasal 20 Undang-Undang Hak Tanggungan yakni:

1. Apabila debitor cidera janji, maka berdasarkan:

a) Hak pemegang hak tanggungan pertama untuk menjual objek hak tanggungan sebagaimana dimaksud dalam Pasal 6 Undang-Undang Hak Tanggungan, atau

b) Titel eksekutorial yang terdapat dalam dimaksud dalam Pasal 14 ayat (2), obyek hak tanggungan dijual melalui pelelangan umum menurut tata cara yang ditentukan dalam peraturan perundang-undangan untuk pelunasan piutang pemegang Hak tanggungan dengan hak mendahulu dari pada kreditor-kreditor lainnya.

2. Atas kesepakatan pemberi dan pemegang hak tanggungan, penjualan objek hak tanggungan dapat dilaksanakan di bawah

${ }^{13}$ Rachmadi Usman, Pasal-pasal tentang Hak Tanggungan atas Tanah, (Jakarta: Djambatan, 1999), 130. 
tangan jika dengan demikian itu akan dapat diperoleh harga tertinggi yang menguntungkan semua pihak.

3. Pelaksanaan penjualan sebagaimana dimaksud pada ayat (2) hanya dapat dilakukan setelah lewat waktu 1 (satu) bulan sejak diberitahukan secara tertulis oleh pemberi dan/atau pemegang hak tanggungan kepada pihak-pihak yang berkepentingan dan diumumkan sedikitnya dalam 2 (dua) surat kabar yang beredar di daerah yang bersangkutan dan/atau media massa setempat, serta tidak ada pihak yang menyatakan keberatan.

4. Setiap janji untuk melaksanakan eksekusi hak tanggungan dengan cara yang bertentangan dengan cara yang bertentangan dengan ketentuan pada ayat (1), (2), dan (3) batal demi hukum.

5. Sampai saat pengumuman untuk lelang dikeluarkan, penjualan sebagaimana dimaksud pada ayat (1) dapat dihindarkan dengan pelunasan utang yang dijamin dengan Hak tanggungan itu beserta biaya-biaya eksekusi yang dikeluarkan.

Berdasarkan ketentuan tersebut, apabila kreditor cidera janji, objek hak tanggungan dijual melalui pelelangan umum menurut cara yang ditentukan dalam peraturan perundang-undangan yang berlaku dan pemegang hak tanggungan berhak mengambil seluruh atau sebagian dari hasilnya untuk pelunasan piutangnya, dengan hak mendahului dari para kreditor yang lain. Pencairan objek jaminan kredit dapat dilakukan berdasarkan ketentuan Pasal 20 Undang-Undang Hak Tanggungan yang menetapkan cara pencairan objek jaminan utang yang diikat dengan hak tanggungan melalui eksekusi dan penjualan di bawah tangan.

1. Berdasarkan ketentuan Pasal 6 Undang-Undang Hak Tanggungan melalui cara parate eksekusi, "Apabila debitor cidera janji, pemegang hak tanggungan pertama mempunyai hak untuk menjual objek hak tanggungan atas kekuasaan sendiri melalui pelelangan umum serta mengambil pelunasan piutangnya dari hasil penjualan tersebut". Berdasarkan ketentuan tersebut, hak pemegang hak tanggungan pertama untuk menjual objek hak tanggungan atas kekuasaan sendiri 
yang diperkuat dengan janji yang tersebut dalam Pasal 11 ayat 2 huruf e Undang-Undang Hak Tanggungan. Hak tersebut harus diperjanjikan terlebih dahulu oleh para pihak dalam Akta Pembebanan Hak Tanggungan (APHT).

2. Titel eksekutorial yang terdapat dalam sertifikat hak tanggungan sebagaimana dimaksud dalam Pasal 14 ayat 2 Undang-Undang Hak Tanggungan. Ketentuan Pasal 14 UUHT menyatakan,

1) Sebagai tanda bukti adanya hak tanggungan, kantor pertanahan menerbitkan sertifikat hak tanggungan sesuai dengan peraturan perundang-undangan yang berlaku.

2) Sertifikat hak tanggungan sebagaimana dimaksud pada ayat (1) memuat irah-irah dengan kata-kata "Demi Keadilan Berdasarkan Ketuhanan yang Maha Esa".

3) Sertifikat hak tanggungan sebagaimana dimaksud pada ayat (2) mempunyai kekuatan eksekutorial yang sama dengan putusan pengadilan yang telah memperoleh kekuatan hukum tetap dan berlaku sebagai pengganti grosse acte hypotheek sepanjang mengenai hak atas tanah.

4) Kecuali apabila diperjanjikan lain, sertifikat hak atas tanah yang telah dibubuhi catatan pembebanan hak tanggungan sebagaimana dimaksud dalam Pasal 13 ayat (3) dikembalikan kepada pemegang hak atas tanah yang bersangkutan.

5) Sertifikat hak tanggungan diserahkan kepada pemegang hak tanggungan.

Berdasarkan ketentuan Paasal 14 Undang-Undang Hak Tanggungan tersebut, sertifikat hak tanggungan memiliki kekuatan eksekutorial, seperti putusan pengadilan yang mempunyai kekuatan hukum yang tetap. Kedua cara eksekusi hak tanggungan di atas harus dilaksanakan melalui cara lelang umum, tetapi karena penjualan dengan cara tersebut tidak selalu menghasilkan harga yang lebih tinggi, maka berdasarkan Pasal 20 ayat 2 UndangUndang Hak Tanggungan, penjualan objek hak tanggungan dapat dilakukan di bawah tangan. Hal ini dimaksudkan untuk 
mempermudah dan mempercepat proses penjualan serta memperoleh harga yang lebih tinggi.

\section{Penutup}

Rumah susun yang didirikan dengan prinsip strata title merupakan suatu lembaga pemilikan yang memberikan hak kebendaan, yaitu yang terdiri dan hak perorangan atas unit satuan rumah susun dan hak bersama atas tanah, benda dan bagian bersama yang kesemuanya merupakan satu kesatuan yang tidak terpisahkan dengan satuan-satuan yang bersangkutan. Kepada pemilik, diterbitkan bukti kepemilikan yang kuat berupa Sertifikat Hak Milik Atas Satuan Rumah Susun (HMSRS).

Kepemilikan rumah susun menurut Undang Undang Perumahan dan Permukiman dapat dilakukan dengan cara kredit berdasarkan Perjanjian Kredit Perbankan berupa kredit kepemilikan apartemen atau rumah susun, di mana HMSRS dijadikan jaminan kredit dengan diikat dengan hak tanggungan sebagaimana ketentuan Pasal 47 ayat (5) UU Rumah Susun. Hal ini dimungkinkan karena rumah susun memberikan hak kepemilikan perseroangan atas satuan rumah susun. Selain kredit kepemilikan atas satuan rumah susun, tanah di mana apartemen nantinya dibangun, dibebani Hak Tanggungan (HT) yaitu dijadikan sebagai jaminan kredit yang dimaksudkan untuk membiayai pelaksaan pembangunan rumah susun yang telah direncanakan di atas tanah yang bersangkutan dan yang pemberian kreditnya dilakukan secara bertahap, sesuai dengan pelaksanaan pembangunan rumah susun tersebut.

Dalam menjalankan prinsip kehati-hatian, bank tidak akan berani memberikan pinjaman atau kredit kepada masyarakat tanpa adanya jaminan. Hak milik atas satuan rumah susun dapat dijadikan objek jaminan kredit dan diikat dengan hak tanggungan, sebagaimana dalam ketentuan Pasal 47 ayat (5) Undang-Undang Rumah Susun. Objek jaminan hak milik atas satuan rumah susun adalah bukan tanahnya, melainkan hak milik atas satuan rumah 
susunnya beserta bagian bersama, benda bersama sebesar bagian pemilik hak milik atas satuan rumah susun.

Definisi yang terakhir ini difokuskan pada pengaturan pada hak-hak kreditur semata-mata, tetapi tidak memperhatikan hakhak debitur. Padahal subjek kajian hukum jaminan tidak hanya menyangkut kreditur semata-mata, tetapi juga erat kaitannya dengan debitur. Sedangkan yang menjadi objek kajiannya adalah benda jaminan. Dari berbagai kelemahan definisi tersebut, maka dua definisi di atas perlu dilengkapi dan disempurnakan.

Syarat-syarat untuk menjadikan hak milik atas satuan rumah susun sebagai jaminan dalam kredit di bank adalah adanya tanda bukti hak yaitu sertifikat hak milik atas satuan rumah susun, pembuatan akta pemberian hak tanggungan yang dilakukan di hadapan PPAT yang didahului dengan perjanjian hutang piutang yang dijamin, janji-janji yang dimuat dalam APHT dan telah didaftarkan di kantor pertanahan selambat-lambatnya 7 (tujuh) hari kerja setelah penandatanganan APHT oleh PPAT.

Landasan hukum atas eksekusi hak tanggungan atas satuan rumah susun terdapat dalam Pasal 20 Undang-Undang Hak Tanggungan, di mana objek hak tanggungan dijual melalui pelelangan umum menurut cara yang ditentukan dalam peraturan perundangundangan yang berlaku, dan pemegang sertifikat hak tanggungan berhak mengambil seluruh atau sebagian dari hasilnya untuk pelunasan piutangnya, dengan hak yang mendahului dari pada kreditur-kreditur yang lain.

\section{Daftar Pustaka}

Salim. Perkembangan Hukum Jaminan di Indonesia. Jakarta: Rajawali Pers, 2008.

Hartanto, J.Andy dan Eman Ramelan. Problematika Hukum Hak Milik atas Satuan Rumah Susun. Yogyakarta: Laksbang Grafika, 2013.

Harahap, M. Yahya. Ruang Lingkup Permasalahan Eksekusi Bidang Perdata, Jakarta: Sinar Grafika, 2009. 
Herman Hermit. Komentar atas Undang-undang Rumah Susun. Bandung: Mandar Maju, 2009.

Masjchoen Sofwan, Sri Soedewi. Hukum Jaminan di Indonesia, Pokokpokok Hukum Jaminan dan Jaminan Perorangan. Yogyakarta: BPHN dan Liberty, 1980.

Sitorus, Oloan dan Balans Sebayang. Kondominium dan Permasalahannya. Yogyakarta: Mitra Kebijakan Tanah Indonesia, 1998.

Soerjono dan Mamudji. Penelitian Hukum Normatif. Jakarta: Raja Grafindo Persada, 2015.

Sutedi, Adrian. Hukum Rumah Susun \& Apartemen. Bandung: Sinar Grafika, 2012.

Tanamu, Taufik Lan. "Kedudukan Hak Milik atas Satuan Rumah Susun sebagai Jaminan Kredit Perbankan". Lex Privatum Universitas Samratulangi. Vol. III No. 2 April-Juni 2015.

Wangsawidjaja Z., Pembiayaan Bank Syariah. Jakarta: Gramedia Pustaka Utama, 2012.

\section{Jurnal/Makalah}

Putri Paramita. "Eksistensi Dan Kekuatan Eksekutorial Sertipikat Hak Tanggungan Terhadap Hak Milik Atas Satuan Rumah Susun Sebagai Jaminan Hutang Dalam Perjanjian Kredit Di Bank", Jurnal Repertorium Universitas Sebelas Maret Surakarta. Edisi 2 Juli-Desember 2015.

Purbandari." Hak Milik Atas Satuan Rumah Susun Sebagai Jaminan Kredit", Jurnal Pepertorium Universitas Mpu Tantular Jakarta. Volume 10 No. 3 Desember 2013.

\section{Undang-Undang}

Kitab Undang-Undang Hukum Perdata

Undang-Undang Nomor 5 Tahun 1960 tentang Peraturan Pokok Agraria

Undang-Undang Nomor 4 Tahun 1996 tentang Hak Tanggungan

Undang-Undang Nomor 10 Tahun 1998 tentang Perbankan

Undang-Undang Nomor 20 Tahun 2011 tenang Rumah Susun 